revealed by these returns is not an isolated instance, for the crop of 1935 was also very low. Damage by spring frosts and inadequate pollination are doubtless causes of low yield, but it should be possible for modern science to raise the apple's cropping potentialjties above $\mathbf{5 0}$ per cent in most years.

\section{A Practical Form of Electrophoresis Apparatus}

IT has long been known that proteins differ widely in their rates of migration in an electric field, and many attempts have been made to use this phenomenon for purposes of separation and identification by so-called 'electrophoresis'. The principle is par. ticularly attractive since even highly unstable substances are unlikely to be damaged by the treatment. One is therefore at first surprised at the scanty results yielded so far by so promising a method. The reason is that until recently no apparatus had been designed which could claim to have overcome the many technical difficulties. In the last few years, however, there has been steady improvement in this respect, associated largely with the names of Dr. Theorell of Stockholm and Prof. Tiselius of Uppsala. The latest form of Tiselius apparatus, which has now been placed on the market by Messrs. F. Hellige and Co., of Freiburg, enables the separation to be followed both optically and analytically, while the resolving power for small differences of mobility has been greatly increased. A direct result of these improvements has been the detection and isolation of the three components of serum globulin (Tiselius, Biochem. J., 31, 1464; 1937) which has answered an old and much disputed question. The apparatus is already in use in several other laboratories, and promises a host of further interesting results, for example, in the study of pathological sera, immune bodies and enzymes.

\section{Quekett Microscopical Club}

THE Quekett Microscopical Club is holding its annual conversazione on October 11 at 7.30 p.m. at Burlington House, Piccadilly, London, in the rooms of the Royal Society. Dr. Arnold Renshaw of Manchester will lecture upon the microscope in the detection of crime. It is not generally known that pieces of tissue (flesh, etc.) can be cut in slices so thin as a twenty-five-thousandth of an inch. A film made by Mr. Pittock of the Department of Anatomy and Embryology, University College, Gower Street, will be projected following Dr. Arnold Renshaw's lecture, showing all the stages in preparation and the actual cutting of these sections. Eighty microscopes will be set up each showing different specimens. In addition there will be several demonstrations. Mr. Edwards of the Haslemere Museum will give continuous projection during the evening of living pond-life. A group of members will show the method of collecting, cleaning, etc., of Diatomaceæ. Methods of recording by means of drawing specimens and structures seen under the microscope will also be demonstrated. Dr. Gunther, of the Old Ashmolean, Oxford, will stage a demonstration of contributions by the late Mr. E. M. Nelson to microscopy. In addition to this, Dr. Gunther will give a demonstra- tion of the original works of Hooke, showing proofs of the plates and the first editions of his book. It is hoped that the Royal Society, which owns a Hooke microscope, will exhibit it. Demonstrations are also expected from the British Museum (Natural History), King's College, Queen Mary College, etc. Cards of admission can be obtained from the Assistant Secretary, Miss Arnold, 58 Warwick Road, Ealing, W.5.

\section{Announcements}

Dr. Harold J. Plenderleith has been appointed deputy keeper in charge of the research laboratory of the British Museum, in succession to Dr. Alexander Scott, who has been honorary director of the laboratory since its institution in 1919 .

THE following representatives to the Scientific Advisory Committee of the Trades Union have recently been appointed by the General Council : Mr. J. Hallsworth (chairman of the General Council), Mr. E. Bevin, Mr. J. Brown, Mr. C. Dukes, Mr. H. H. Elvin, Mr. G. Gibson, Mr. W. Holmes, Mr. W. Lawther, Mr. G. W. Thomson, and Sir Walter Citrine. On advice furnished by the general officers of the British Association the scientific representatives on the committee will be : nutrition and agriculture, Sir Daniel Hall and Sir John Orr; physics, Prof. Allan Ferguson and Prof. P. M. S. Blackett; chemistry, Prof. F. G. Donnan and Prof. A. C. G. Egerton; physiology and psychology, Prof. Winifred Cullis; population, Prof. L. Hogben; metallurgy, Prof. J. D. Bernal; geology and geography, Prof. P. G. H. Boswell ; engineering, Mr. J. S. Wilson.

The Hydrobiology and Fisheries Laboratory, Alexandria, a description of which appeared in NATURE of June 18, p. 1107, has, by Royal decree, been named the Fouad I Institute of Hydrobiology and Fisheries.

The fiftieth anniversary of the foundation of the Pasteur Institute of Paris will be celebrated on October 26 in the presence of the President of the French Republic and the Minister of Health.

The American Academy of Arts and Sciences gives notice of the Francis Amory Septennial Prize for outstanding contributions to knowledge of diseases of the human sexual organs. The first award, which will be made in 1940, will exceed 10,000 dollars. There will be no formal nomination and no formal essays or treatises will be required. Further information can be obtained from the Amory Fund Committee, American Academy of Arts and Sciences, 28 Newbury Street, Boston, Mass., U.S.A.

A PRINTED supplement (Bulletin 1937, No. 3, Supplement No. 1, Washington, G.P.O., 1938. 10 cents) to the index to Public Affairs Pamphlets has now been issued by the Office of Education, United States Department of the Interior. It contains an annotated list of a further 552 pamphlets together with a report on the pamphlet display demonstration centres, and author, subject and title indexes. 